\title{
Hard Cases and Human Judgment In Islamic and Common Law
}

\author{
by \\ John Makdisi*
}

Every legal system in tune with the living practical reality of societal change experiences the need for corresponding change within. This change does not proceed in a predetermined orderly fashion. Human judgment plays a significant role in the reasoned elaboration of the law, in order to address the multivarious situations presented by the human condition; yet this change must be implemented within channels of reform that are recognized as legitimate in order to maintain acceptance and stability. Arbitrary personal opinion is never acceptable in a legal system where the rule of law prevails.

This article will explore different modes of legal reasoning in Islamic law. After defining and rejecting arbitrary decision-making as a recognized mode of legal reasoning, it will discuss three other modes that are recognized as legitimate in Islamic law - qiyass, istihsān, and istisläh. These modes of legal reasoning involve human judgment and may generate different results when applied by different jurists. The purpose of this discussion is to compare similar modes of legal reasoning in the common law with those in Islamic law. Such a comparison will reveal the tension between flexibility and constraint that defines the whole legal process.

\section{Arbitrary decision-making}

There is reported in the Criminal Law Quarterly ${ }^{1}$ a fictional opinion by Blue, J., that despite its light-hearted character paints a poignant picture of arbitrariness. It reads as follows:

This is an appeal by the Crown by way of a stated case from a decision of the magistrate acquitting the accused of a charge under the Small Birds Act, R.S.O., 1960, c.724, s.2.

- Dean and Professor of Law, University of Tulsa College of Law.

1. Note, Judicial Humour-Construction of a Statute, 8 CRIM. L. Q. 137 (1965) (reproduced in a memorandum prepared by $W$. Barton Leach and printed in CASEs and Text on Property (A. James Casner \& W. Barton Leach eds., Supp. 1980)). 
The facts are not in dispute. Fred Ojibway, an Indian, was riding his pony through Queen's Park on January 2, 1965. Being impoverished, and having been forced to pledge his saddle, he substituted a downy pillow in lieu of the said saddle. On this particular day the accused's misfortune was further heightened by the circumstances of his pony breaking its right foreleg. In accord with Indian custom, the accused then shot the pony to relieve it of its awkwardness.

The accused was then charged with having breached the Small Birds Act, s.2 of which states:

2. Anyone maiming, injuring or killing small birds is guilty of an offence and subject to a fine not in excess of two hundred dollars.

The learned magistrate acquitted the accused holding, in fact, that he had killed his horse and not a small bird. With respect, I cannot agree.

In light of the definition section my course is quite clear. Section 1 defines "bird" as "a two legged animal covered with feathers." There can be no doubt that this case is covered by this section.

Counsel for the accused made several ingenious arguments to which, in fairness, I must address myself. He submitted that the evidence of the expert clearly concluded that the animal in question was a pony and not a bird, but this is not the issue. We are not interested in whether the animal in question is a bird or not in fact, but whether it is one in law. Statutory interpretation has forced many a horse to eat birdseed for the rest of its life. . .

Counsel relied on the decision in $R e$ Chicadee, where he contends that in similar circumstances the accused was acquitted. However, this is a horse of a different colour. A close reading of that case indicates that the animal in question there was not a small bird, but, in fact, a midget of a much larger species. Therefore, that case is inapplicable to our facts.

Counsel finally submits that the word "small" in the title Small Birds Act refers not to "Birds" but to "Act", making it The Small Act relating to Birds. With respect, counsel did not do his homework very well, for the Large Birds Act, R.S.O. 1960 , c. 725 , is just as small. If pressed, I need only refer to the Small Loans Act R.S.O. 1960, c. 727 which is twice as large as the Large Birds Act.

It remains then to state my reason for judgment which, simply, is as follows: Different things may take on the same 
meaning for different purposes. For the purpose of the Small Birds Act, all two-legged, feather-covered animals are birds. This, of course, does not imply that only two-legged animals qualify, for the legislative intent is to make two legs merely the minimum requirement. The statute therefore contemplated multi-legged animals with feathers as well. Counsel submits that having regard to the purpose of the statute only small animals "naturally-covered" with feathers could have been contemplated. However, had this been the intention of the legislature, I am certain that the phrase "naturally-covered" would have been expressly inserted just as 'Long' was inserted in the Longshoreman's Act.

Therefore, a horse with feathers on its back must be deemed for the purposes of this Act to be a bird, and a fortion, a pony with feathers on its back is a small bird.

Counsel posed the following rhetorical question: If the pillow had been removed prior to the shooting, would the animal still be a bird? To this let me answer rhetorically: Is a bird any less of a bird without its feathers?

\section{Appeal allowed. ${ }^{2}$}

This opinion demonstrates rather sardonically how the law can be twisted to accommodate unintended objectives. The judge may have been intent on protecting what he considered to be the right to life of ponies. Of course, it does not take much horse sense to see that the statute was misinterpreted. The statute's definition of a bird does not include ponies, no matter how many characteristics a bird and a pony have in common. The result may have been considered desirable in terms of animal protection, but it was decided in a manner that would permit almost any rule or principle to be interpreted for other than the true intent behind its formulation. If such a technique were to prevail in our legal system, it would tear apart the fabric of the law and ultimately destroy its original identity. Judges would no longer be governed by law; rather, the law would be governed by a judge's own personal inclinations. Judge and former Professor Robert E. Keeton has succinctly stated, "Judges are not free to make choices expressing their own personal values. Their professional obligation is one of reasoned choice - or as it is often described - principled adjudication." "3

Arbitrary personal opinion is similarly rejected in Islam. Shäfii, one of the founding fathers of Islamic jurisprudence in the ninth century,

2. Id.

3. Robert E. Keeton, Judging 19 (1990) (footnote omitted). 
stated that no decisions by arbitrary personal opinion of jurists were allowed. He declared that a jurist must use $i j t i h \bar{a} d$, a concerted personal effort to decide cases through the use of qiyās, a form of reasoning by analogy. This reasoning is based on solutions found in the sources of the law and excludes whim and personal preference. ${ }^{5}$

\section{QrYĀs}

The primary sources of Islamic law are the Koran (the sacred scripture collecting revelations made to the Prophet between 609-632) and the sunna (the decisions, words, actions, and tacit approvals of the Prophet, which are related in traditions called hadiths). Because Islamic law is generally conceived as a divine law, all law derives from God's commands within these two sources, rather than from nature as derived from only the human mind. ${ }^{6}$ Nevertheless, the Koran and sunna directly address relatively few human situations. When situations arise that are not directly covered in the sources, there must be some way of deriving solutions to the problems they present. The primary mode of legal reasoning to solve these problems is qiyās.

Qiyās is a form of reasoning by analogy from cases found in the Koran and sunna. According to Shāfi ' $\bar{i}$, ' where there is no case on point in the Koran or sunna to govern a new case, a similar case in the sources may be found whose ruling is extended to the new case if both have a common basis (asl), otherwise known as an efficient cause ('illa). ${ }^{8}$ For example, the case of a child hitting one's parents is not directly covered in the Koran or sunna. However, there is a ruling in the Koran (XVII:23) that forbids children to speak disrespectfully to their parents: "Say not 'Fie' to them (parents) neither chide them, but speak to them graciously." The common basis (asl) in both cases is harm to the parents, that is, by battery and disrespectful language.

4. Joseph Schacht, The Origins of Muhammadan Jurisprudence 122, 127 (1953)[hereinafter Sснаснт].

5. Id. at 127. According to Shafi ${ }^{\prime} \bar{i}$, " $[0] n$ all matters touching the [life of a] Muslim there is either a binding decision or an indication as to the right answer. If there is a decision, it should be followed; if there is no decision, the indication as to the right answer should be sought by ijtihäd, and ijtihäd is qiyas." Malcolm H. KerR, Islamic Reform: The Political and Legal Theories of Muhammad 'Abduh and RASHID RIDĀ 76 (1966)[hereinafter KERR].

6. See KerR, supra note 5 , at 76 .

7. Died 820.

8. Sснаснт, supra note 4, at 125; KERR, supra note 5, at 67. 
Therefore, the prohibition in the Koran is applied to the new case. ${ }^{9}$

There are two premises in the above analogy. The first premise is that the common basis (asl) in the Koranic case of parental disrespect is harm to the parents. The second is that striking a parent is harmful. Neither premise is likely to give rise to dispute in this situation, but other situations are less clear. For example, there is a rule that a sale entailing risk is prohibited. The sale of a non-existent commodity is arguably a case entailing risk and therefore null and void, but it could also be argued that such a case does not entail risk. Ghazāii, ${ }^{10}$ a twelfth century jurist, discusses such a disagreement:

If there is disagreement concerning the second premise - that is, concerning the existence of the cause in the assimilated case subsequent to admitting that the [existing] property is the cause - the cause may be identified either through sensory perception if the property is sensory, or through custom or language. It may also be identified through seeking definition (hadd) and conceptualizing (tasawwur) the inner reality of the thing, or through revealed scriptural evidence. ${ }^{11}$

Ghazāli then proceeds to explain that in the case of the risky sale, an adversary who disagrees on the risk aspect of the sale of non-existent commodities "may be answered that this is known through custom ( $a d a$ ) in which practice ('urf) decides." ${ }^{12}$ Ghazali highlights the discretionary element of legal reasoning in this passage. Because not every risk can be named in the law, jurists must determine whether a situation is risky by using their experiential or conceptual judgment.

The common law has a similar approach for determining the applicability of the common basis (asl) or cause ( $\left.m a^{\prime} n \bar{a}\right)$ of a decided case. Pierson $v$. Post, ${ }^{13}$ a well-known decision in the area of property law, held that there was no ownership of a wild animal when a hunter failed to kill or capture a fox he was chasing before another person

9. See Hallaq, Non-Analogical Arguments in Sunni Juridical Qiyās, 36 Arabica 286, 289-96 (1989)(discussing the Islamic jurists' arguments for and against including this case as one of qiyass) [hereinafter Hallaq]. For other examples of qiyās, see KERR, supra note 5, 66 (discussing the ban on intoxicating drinks and the guardianship rights over women seeking marriage).

10. Died 1111.

11. Ghazali, Concerning the Explication of the Modes of Analytical Demonstration used in Legal Matters, translated in Hallaq, Logic, Formal Arguments and Formalization of Arguments in Sunni Jurisprudence, 37 Arabica 315, at 342 (1990)[hereinafter Arabica].

12. Id. at 343 .

13. 3 Cai. R. 175 (N.Y. Sup. Ct. 1805). 
killed and carried it off. The cause (ma'nā, in Islamic law) of ownership was stated to be possession based on an analysis of previous cases. The question in the case was whether pursuit of the fox was sufficient to give the original hunter possession so as to produce the legal effect of ownership. It was decided that pursuit alone was insufficient although mortal wounding might have been found sufficient. Deprivation of natural liberty as an element of possession was a consideration in determining that pursuit was not enough for possession. The dissent in the case was inclined to submit the case for arbitration by sportsmen, advocating the use of custom to determine the applicability of the possession concept.

Pierson illustrates the need for human judgment in common law decisions as in Islamic law decisions to determine the second premise: the applicability of an existing common basis (asl) or cause (ma' $n \bar{a})$ to a new case. Human judgment is also needed to determine the first premise: what the common basis is. For example, it is reported in the sunna that the sale of wheat for a different quantity of wheat is usurious. ${ }^{14}$ In determining whether a similar sale of quince is usurious, it may be argued that the cause of wheat being subject to the rules on usury is its edibility, and since quince is edible, it too is subject to the rules on usury. Ghazali comments on the nature of disagreement in this case:

Disagreement may be assumed to arise concerning the first premise, while the second premise is agreed upon. The adversary may argue: "I agree that quince is edible but $I$ do not agree that edibility is the cause of [prohibiting] usury, or that edible objects are usurious. Rather, some edible objects are usurious but not due to their being edible." 15

Ghazāli also discusses how the cause of a given ruling in any one case in the sources may be determined:

If there is disagreement concerning the first premise, it cannot be settled except through legal evidence, for what is being argued, namely, edibility being the cause, is legal. This cause may be established by the revealed, unambiguous texts, by textual allusions (im $\bar{a}$ ), by the setting of the case, by the occurrence [of the effect] with the occurrence of the property, or by effectiveness ( $t a^{\prime}$ thir). The latter, as has been previously

14. Schacht, Ribā, 6 First Encyclopaedia of Islam 1913-1936 1148 (1987).

15. ARABICA, supra note 11 , at 341 . 
mentioned, is establishing the effect of the cause in the essence of the judgment in another case through a text, consensus, relevance (munāsaba), or coextensiveness and coexclusiveness. Or through consensus reached on the indispensability of a sign ('alāma), or, subsequently, through investigation (sabr). This is in order to negate all signs aside from that which has been stipulated - as we have mentioned concerning the premises of argumentum a simile. [The stipulated sign] is also termed a cause ( $i l l a$ ) according to the majority of legal theoreticians. Shâfi' $i$ also pointed to this cause when speaking of edibility and cash. ${ }^{16}$

This determination is one based on the sources of the law but still requiring the exercise of human judgment to determine what the law is. The cause ('illa) is not always revealed explicitly in the sources. Therefore examination and interpretation are necessary. It is possible in these circumstances to produce a mistaken opinion, but the jurisconsult who makes a sincere effort is still rewarded in the Hereafter despite the mistake. If his opinion is correct, he is doubly rewarded. ${ }^{17}$ However, some interpretations based on human judgment eventually may be rejected as false, and new interpretations adopted.

\section{IsTIHSĀN ${ }^{18}$}

Islamic law contains within itself a mechanism for self-correction. When the process of reasoning by analogy in a particular case is determined to be wrong, it is corrected through the process of istihsān. This mode of legal reasoning is really no different than qiyās except that the new qiyass is considered a better qiyas than the one previously used in the same case. Ibn Taymiya, a jurist of the fourteenth century, provides one of the best explanations of this concept.

For Ibn Taymiya, reasoning by analogy must be based on a valid cause ('illa sahiha), and a valid cause may not stand in contradiction to a text from the sources of the law. If it does, the text stands and

16. Id. at 341-42 (footnotes omitted). For an explanation according to Qaräfi (died 1285) of these means of identifying the 'illa (cause) in a given case, see KERR, supra note 5 , at $68-72$.

17. George Makdisi, The Rise of Colleges: Institutions of Learning in IsLAM AND THE WEST 277 (1981); see also KERR, supra note 5, at 63.

18. This section is reprinted (with minor modifications) from J. Makdisi, Legal Logic and Equity in Islamic Law, 33 AM. J. OF CoMP. L. 63, 83-87 (1985): 
the reasoning by analogy is invalid (fasid)..$^{19}$ Any concept of istihsān which allows reasoning by analogy to stand in contradiction to a text from the sources is invalid. ${ }^{20}$ The rationale for invalidating the reasoning by analogy in such a case is that the texts of the Islamic law sources do not always specify the cause or explain the meaning behind it which produces the legal norm in a particular case. There may be an indication (dalil) in the sources as to what the cause may be, such as an affinity (munāsaba) or some other type of relationship between cause and legal effect which is considered the determinant of the norm (manāt al-hukm), ${ }^{21}$ but human opinion which is subject to error ultimately determines the meaning behind the cause on which the legal norm is based. Therefore, when the cause is found to exist in a new case and the legal norm cannot be applied without contradiction of another text from the sources, the cause may accordingly be limited in the sense that the meaning by which the cause was originally determined to exist may be modified or completely changed.

The factor which determines whether the cause is to be completely discarded or only modified to include certain cases is the existence of a meaning ( $\left.m a^{\prime} n \bar{a}\right)$ for that cause which can be derived from the sources and which distinguishes the new case from the original case. If the two cases can be so distinguished, the cause may be limited without changing the legal solutions to cases which still fall within the now restricted meaning of the original cause. If no separation in principle can be

19. Ibn Taymiya, Mas'alat al-Istihsān, edited by G. Makdisi, Ibn Taimiya's Autograph Manuscript on Istihsān: Materials for the Study of Islamic Legal Thought, in George Makdisi (ed.), Arabic and Islamic Studies in Honor of Hamilton A.R. Gibb 455 (6-8) (1965) [hereinafter IsTIHSĀN].

20. See id. at $454(22-24), 455(2-5)$.

21. Note the concordance of Ibn Taymiya with Ghazali's concept of 'illa, described in Brunschvig, Valeur et fondement du raisonnement juridique par analogie d'après al-Gazāli, 2 Robert Brunschvig (ed.), Études D'Islamologie 363, at 370-371 (1976):

The qiyass al-illa, which is by far the more important and the more elaborated [as opposed to the qiyās ash-shabäh], recognizes in turn an internal hierarchy founded on that which decides the existence or the choice, in the basic case, of a "cause" or "illa, which is the "determinant of the norm" (manāt al-hukm). Of course, it is not a question of physical nor purely rational cause, but of legal motive, ratio legis, on the juridico-religious plane which is that of Islam. The ways by which this illa is recognized and established - operation called ta'lin - are of three sorts, by decreasing order of prestige and authority, recalling the ordinary classification of sources of Islamic law: textual source (naql), consensus (ijmā), rational deduction (istinbāt). [Author's translation from the French]

For an explanation of these three types, see id. at 371-386. 
made between the two cases, the cause must fail for not being universally valid. Ibn Taymiya calls istihsān the limitation of the cause either with its modification, or with its complete nullification. It is not possible to admit an exception to the application of a legal norm in a case where its cause exists and cannot be explained by a distinguishing factor. ${ }^{22}$

The true reasoning by analogy is the equalization between similar things and the separation between different things. Istihsān fits within this framework as a methodological device for correcting a mistake or omission which has been made in studying the sources. ${ }^{23}$ It limits the cause which has been conceived too broadly and redefines it to allow for the exceptional case. ${ }^{24}$ As Ibn Taymiya puts it, "[t]here is nothing

22. See IstihsĀN, supra note 19, at 459 (21), 460 (4-11), 463 (1), $464(6-8,13-$ 19), 468 (7-10), 469 (9-13). Compare Ghazāli's idea of takhsis al-illa, described in Brunschvig, supra note 21 , at 383-384.

23. See IstIHSĀN, supra note 19, at 464 (20-23), 469 (2-13).

24. With this clarification of the nature of istihsan, Ibn Taymiya proceeds to reexamine the cases of istihsän which Ahmad ibn Hanbal had interpreted as contrary to reasoning by analogy. He reaches the following conclusions:

(a) In the case of the mudāraba contract, the reasoning by analogy and the istihsan, as well as the cause of the former and the separating meaning of the latter, are derived (mustanbat). One or both causes - that of the original qiyäs and that of the new qiyās (istihsān) - might be invalid. In this case, it is the istihsān which is followed, because the reasoning by analogy is based on the idea that the agent is like one acting for hire, but he is really a partner in the profit. This is the separating meaning. The one acting for hire is not authorized to do other than he is directed, but this does not mean that his act is without effect. It is conditional on the ratification of the hirer. To get his profit the hirer must ratify the free disposal by the agent; otherwise the sale is null and void. Once the act of the agent is ratified, the hired one gets his right, i.e., his wage, and the hirer gets his profit. Yet ratification in the case of the agent who is a partner in the profit means that he is authorized to take his right, i.e., a share in the profit. Therefore he takes his share rather than the fair wage. Istihsān, supra note 19, at 472 (16) - 474 (17). But see Abraham Udovitch, Partnership and Profit in Medieval Islam at 245-246 (1970), in which Shaybāni (died 803) is cited for treating the mudāaba contract as a contract for hire (ijāra) when the agent violates a legitimate restriction placed on him by the investor.

(b) In the case of the tayammum, the reasoning by analogy is correct and not the istihsān. IstıHSĀN, supra note 19, at 469 (19) - 472 (15).

(c) In the case of the one who usurps land and plants it, the istihsann is based on a hadith (tradition) and the reasoning by analogy which is inconsistent with the istihsan is invalid because there is no text which shows its authenticity. Concerning the cost owing the planter, reasoning by analogy considers him a usurper, but in fact he is not because the seed with which he planted belongs to him. Therefore, he is entitled to receive back what he put into the land.

IstiHSĀN, supra note 19, at 475 (10) - 476 (9).

(d) In the case of the purchase of the land of Sawād, a separation is made between 
in the shari'a [Islamic Law] opposed to a true reasoning by analogy.',25 Thus, istihsän is a method for choosing between two or more conflicting solutions for a case at hand where those solutions are based on different sources of Islamic law. ${ }^{26}$ Furthermore, the method for making this choice must be rational, based on a consistent set of priorities or on the logical analysis of the meaning underlying the rules.

The idea of conflict resolution, inherent in the nature of law, exists not only between opposing parties through dispute settlement, but also between opposing legal norms through legal decision-making. If conflict arises between established legal principles, the notions of consistency, coherence and certainty in the law require a reconciliation of these principles or a rejection of one in favor of the other. In the common law, this conflict may occur between a case precedent and a newly enacted statute, in which case the statute will prevail as the source of law having greater priority. Conflict may also occur between two case precedents. In such an instance, an attempt is made to reconcile their principles before resorting to the rare phenomenon of overruling one in favor of the other. ${ }^{27}$ The process of reconciling the principles of two conflicting case precedents uses a widely-recognized technique of legal reasoning in the common law. This technique was described in 1958 by Henry Hart and Albert Sacks as the "reasoned distinction of precedent. ${ }^{28}$ In order to provide a comparative basis on which to evaluate istihsān as a rational method of legal reasoning, we will examine this technique as illustrated in Berenson v. Nirenstein. ${ }^{29}$

Berenson involved a defendant who offered "to act as agent and broker for the plaintiff in seeking to buy" 30 all the shares of stock of

the purchase and the sale because the cause is existing in the latter and not the former. The purchase is not for a worldly objective, so it is permissible. IstiHsÃN, supra note 19 , at $476(10)-477$ (1).

25. “Laysa fi 'sh-shari'a mā yukhālifu qiyāsan sahihan." IBN TAYMiYA, AL-QIYĀs

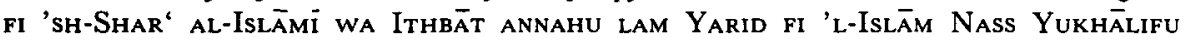
'L-QIYĀs AS-SAHİ 7 (5-6) (1346 H.), translated into French by Laoust in Contribution à une Etude de la méthodologie canonique de Taki-d-Dín Ahmad b. Taimíya 113, at 115 (1939); see also IstiHSĀN, supra note 19, at 465 (4-5).

26. The four recognized sources of Islamic law are the Koran, sunna, consensus and reasoning by analogy. Joseph Schacht, The Origins of Muhammadan JurisPRUDENCE at $1,135(1950,1953)$.

27. Respect for the doctrine of "stare decisis" severely restricts the inclinations of judges to overrule case precedents.

28. Hart \& Sacks, The Legal Process: Basic Problems in the Making and Application of LAW at 407-426 (unpublished ed., 1958).

29. 326 Mass. 285, 93 N.E.2d 610 (1950) (the case used to illustrate the technique of the "reasoned distinction of precedent" in the HART \& SACKs materials).

30. Id. at 610 . 
a certain corporation. The plaintiff " "retained the defendant [Nirenstein] as his broker and agent to effect a purchase of the shares . . . and the defendant [Nirenstein] agreed to act as such broker and agent on behalf of the plaintiff and to use his best efforts to purchase said shares of stock for him." "'31 A firm offer of $\$ 70 /$ share to be made for 4704 shares was authorized by the plaintiff, but thereafter, the defendant, still representing to the plaintiff that he was acting on his behalf, entered into a written agreement with certain trustees of the corporation for the purchase of the shares himself. Plaintiff prayed for injunctive and other relief, but the trial court denied his request, citing Salter $v$. Beal, ${ }^{32}$ among other cases, as precedent. ${ }^{33}$ The case reached the Supreme Judicial Court of Massachusetts, which addressed the issue of an apparent conflict between the Salter line of cases and another set of cases, including Spritz v. Brockton Savings Bank. ${ }^{34}$

The Salter case held that no fiduciary obligation was shown by a defendant who, despite the fact that he was employed by a plaintiff to appraise certain machinery which the latter contemplated buying, bought the machinery for himself. ${ }^{35}$ The principle of the case on which this decision was based was "that a mere engagement to buy in behalf of another without more is not deemed . . . to create a fiduciary relation." ${ }^{36}$ On the other hand, the Spritz line of cases established that the relation of broker to principal involves certain obligations:

The plaintiff [broker] was bound to act solely for the benefit of the defendant [principal] in procuring a customer and in effecting a sale of the property. He could not himself become the purchaser, and he could not secretly enter into an agreement with the buyer that would conflict in any way with the obligation he had assumed of acting in entire good faith in the interest of the defendant. ${ }^{37}$

Faced with reconciling these two lines of cases, the Supreme Judicial Court of Massachusetts reversed the lower court's decree by qualifying the Salter line of precedent and classifying the instant case under the Spritz line of precedent. Its legal argument reads as follows:

31. Id. at 611 .

32. 321 Mass. 105, 71 N.E.2d 872 (1947).

33. 93 N.E.2d at 611 .

34. 305 Mass. 170, 25 N.E.2d 155 (1940).

35. 71 N.E. $2 d$ at 874 .

36. 71 N.E. $2 d$ at 873 .

37. 25 N.E.2d at $156(1940)$. 
The fiduciary obligation toward his principal of one who is acting in the full sense as a broker in the sale or purchase of property rests upon fundamental principles of business morality and honor which are of the highest public interest, and which it is the bounden duty of courts to preserve unimpaired. We do not believe that in deciding the cases [in the Salter line of precedent] the court had in mind a case where the full relation of principal and broker existed. . . [A]t least where, by the conduct of the parties, the full relation of principal and broker has come into existence, including the carrying on of a negotiation between seller and buyer, there has come into existence with it a confidential and fiduciary relation which gives rise to a constructive trust in favor of the principal in property which the broker has acquired for himself in violation of his duty to his principal. We by no means suggest that all of the cases in the first list were wrongly decided, but we do hold that in so far as broad expressions in some of them might be thought at variance with what has just been stated such expressions must be deemed to be qualified by what is here said. ${ }^{38}$

Thus the court found that the distinguishing factor between the two lines of precedent existed in the nature of the relationship between the parties in the cases. For a fiduciary relation to exist, the court reasoned that there must be a sufficient relationship between broker and principal. There existed here a "full relation of principal and broker" which was found to exist in the Spritz line of cases but not the Salter line. Therefore, the principal was allowed to bring suit against the broker in this case.

Human judgment, used to extend the decision in one case to another, can be wrong. The reasoned distinction of precedent in the common law and istihsān in Islamic law are corrective devices that permit a better reasoning by analogy to be substituted for a faulty one. There are situations that arise, however, where no reasoning by analogy is possible from an existing case in the sources. There is a gap in the specific directives of the law and some device is needed to fill the gap. This mode of legal reasoning is called ististah. ${ }^{39}$

38. 93 N.E.2d at 612.

39. Emile Tyan in Méthodologie et sources du droit en Islam, 10 Studia Islamica 79 , at 96 (1959), describes the concept of ististäh as follows:

In its original conception, this method can be summarized in the 


\section{IsTISLĀH}

In the common law a gap in the specific directives of the law is often filled by recourse to the notion of public policy, a determination based on what is right, just, fair, convenient or conducive to order and harmony in society. The principles on which a public policy decision is made are imbedded in the culture and, for that matter, the fabric of the common law. In Islam a similar phenomenon occurs through the concept of istisläh (also maslaha). In Islamic law the general principles of application are found imbedded in the sources of the law - the Koran and the sunna.

Ghazâli defines maslaha broadly as the implementation of the intent of the law (Shar), which is to preserve religion, life, reason, progeny and property. ${ }^{40}$ The rules that exist in the primary sources are an implementation of this intent. For example, the punishment of the apostate preserves religion, and the $h a d d^{41}$ punishments for wine drinking, unlawful intercourse and theft preserve reason, progeny and property respectively..$^{42}$ Maslaha implements the intent of the law where there are no existing rules.

following terms. The matters, the general "interests" (masālih) which, in the government of the community, can prove the object of regulation, are divided into three categories. The first have been effectively recognized and regulated by determined and precise texts of law, - the others, cited in the law, have been nevertheless rejected by a precise text, - the third category is represented by the matters which have not been the object of a determined and precise regulation neither in one sense nor in the other.

The interests of this last category are called masalih mursala (lit.: "interests not tied"' to a precise text). Therefore, in default of texts, the human reason finds itself reduced to its own resources to find the diverse rules of law which the protection of its interests necessitate; as well, the reasoning which, under such conditions, results in the establishment of norms and juridical solutions, is qualified as a method of research "not tied: istidlal mursal". [Author's translation from French]

40. 1 GhazĀLì, Al-Mustasfā min 'Ilm al-Usul at 286-87 (Cairo: Bulāq, 132224H.) [hereinafter MUSTASFA]]. These goals are known as the "five universals" (alkulliyāt al-khams); see KERR, supra note 5, at 69 (discussing Qarāfi). Maslaha literally means that which aims at promoting a benefit or preventing a harm, but Ghazali emphasizes that while these aims are goals for the good of mankind, they do not fit within the legal meaning of the term. KERR, supra note 5, at 92-93.

41. For a summary discussion of the hadd offences, see Joseph Schacht, AN Introduction to Islamic Law at 175-81 (1964); see also, Safwat, Offences and Penalties in Islamic Law, 26 Islamic Q. 149 (1982).

42. Mustasfā, supra note 40 , at 287-88; see KERR, supra note 5 , at 93. 
More specifically, maslaha mursala refers to the implementation of these five interests where there is no one indication in the sources to govern a particular case, but rather many without number. ${ }^{43}$ In such a case where there is no support for a legal principle from one particular source, Ghazali limits the determination of the principle with three requirements. It must be (1) necessary (darwä), (2) definitive (qat'i $\bar{y} y$ a), and (3) universal (kulliya). ${ }^{44}$ For example, if infidels shield themselves with a group of Muslim prisoners and restraint from action by the Muslim army will mean defeat and slaughter for all the Muslims, it is permitted to kill an innocent Muslim used as a shield, despite the fact that this case is not mentioned in the Law. ${ }^{45}$

The preservation of all the Muslims is closer to the intent of the Law because we know definitively ( $q a t^{\prime}$ 'an) that the intent of the Law is the minimization of killing, just as it intends its termination if possible. ... And this would be the consideration of a maslaha known as necessity. ${ }^{46}$

By way of contrast, Ghazali points out that the killing of an innocent Muslim used as a shield by the infidel in a fortress is not permitted since it is not a necessity and victory is not certain. Likewise the throwing of a passenger overboard to save the rest of the people on a boat is not permitted since the destruction of people is not contemplated universally for all Muslims, even though it be for a number. Nor is the eating of a person permitted to prevent a group of people from dying of hunger because the maslaha is not universal. ${ }^{47}$ Ultimately, Ghazāli states that we know by ijma' that the many are not preferred over the few. ${ }^{48}$

43. Mustasfā, supra note 40, at 311. Maslaha mursala means "unrestricted, undefined, independently arrived at benefit" and may be contrasted with maslaha mu'tabara (recognized benefit) and maslaha mulghäh (excluded benefit). KERR, supra note 5 , at $70,80,85$.

44. Mustasfā, supra note 40, at 295-96; see KerR, supra note 5, at 93-94.

45. Mustasfä, supra note 40 , at 294.

46. Id. at 295 (Author's translation from the Arabic). Compare translation in KERR, supra note 5 , at 93.

47. Mustasfā, supra note 40, at 296-97; see KerR, supra note 5 , at 94. Ghazali also discusses the situation where one maslaha may outweigh another and be preferred. He opposes the beating of one accused of theft (which is a maslaha approved by Malik) because there is another maslaha which considers the potential innocence of the accused. The torture of an innocent person outweighs the deterrence factor of the beating. Mustasfā, supra note 40, at 297-98.

48. Mustasfä, supra note 40 , at 314 . Ijma' (consensus) is a confirmatory device in Islamic law. 
An objection is raised that to permit the killing of an innocent Muslim used as a shield when it involves the welfare of the whole Islamic nation contravenes two Koranic provisions ${ }^{49}$ against the killing of believers. Ghazāli answers that, while it is not permitted to contravene a textual source, it is permitted to limit it to exclude a case which is universal and not merely a matter of numbers: ${ }^{50}$

The Law prefers the universal over the particular, and the preservation of the Islamic people from the pillage of the infidel is more important in the intent of the Law than the preservation of the blood of one Muslim. This is settled (maqtu' $b i h i$ ) from the intent of the Law and that which is settled does not need evidence from a source. ${ }^{51}$

Ghazāli demonstrates from this discussion an essentially conservative approach to upholding the law but mitigated in one important respect. Where a necessary, definitive and universal maslaha exists, it may be used as a rule of Law even when it requires the limitation of a Koranic text. This maslaha is not derived by personal opinion or policy judgment but rather from the intent of the Law derived from the sources as a whole.

In the common law we find similar solutions to the problems raised by Ghazāli. During the Canadian rebellion of 1837 , British forces attacked the ship "Caroline" in American territory with innocent people on board in an attempt to block reinforcements and supplies to the rebels and to deprive them of their means of access to the mainland of Canada. The ship was destroyed and two people were killed. Daniel Webster, the American Secretary of State, sent a note on July 27, 1842, to Lord Ashburton, a special minister of the British government, in which he called upon the British Government to show:

[a] necessity of self-defence, instant, overwhelming, leaving no choice of means, and no moment for deliberation. It will be for it to show, also, that the local authorities of Canada, even supposing the necessity of the moment authorized them to enter the territories of The United States at all, did nothing unreasonable or excessive; since the act, justified by the necessity of self-defence, must be limited by that necessity, and

49. See KORAN IV:93 and VI:151.

50. Mustasfä, supra note 40 , at 302-03.

51. Id. at 303 (Author's translation from the Arabic). Compare translation of KERR, supra note 5, at 95 . 
kept clearly within it. It must be shown that admonition or remonstrance to the persons on board the Caroline was impracticable, or would have been unavailing; it must be shown that day-light could not be waited for; that there could be no attempt at discrimination between the innocent and the guilty; that it would not have been enough to seize and detain the vessel; but that there was a necessity, present and inevitable, for attacking her in the darkness of the night, while moored to the shore, and while unarmed men were asleep on board, killing some and wounding others, and then drawing her into the current, above the cataract, setting her on fire, and, careless to know whether there might not be in her the innocent with the guilty, or the living with the dead, committing her to a fate which fills the imagination with horror. A necessity for all this, the Government of The United States cannot believe to have existed. ${ }^{52}$

Self-preservation against innocent people on a national scale is permitted in the case of necessity. Webster stresses that the necessity must be inevitable. By way of contrast, the eating of an innocent person has not been permitted to prevent a group of people from dying of hunger, although the question is debated. ${ }^{53}$ In Queen $v$. Dudley, ${ }^{54}$ two seamen, drifting in the ocean in an open boat without food for several days and with no reasonable prospect of relief before death by starvation, killed and ate a boy who was also on the boat. For this act they were convicted of murder. Although self-defense is permitted against the acts of a person whose life is taken, the Court held that the life of an innocent person may not be taken. The defense of necessity was rejected. In this case of private homicide the Court indicated that there would be no definitive method for determining how the rule was to apply if necessity were permitted as an excuse:

It is not needful to point out the awful danger of admitting the principle which has been contended for. Who is to be the judge of this sort of necessity? By what measure is the comparative value of lives to be measured? Is it to be strength, or intellect, or what? It is plain that the principle leaves to him who is to profit by it to determine the necessity which

52. Quoted in Jennings, The Caroline and McLeod Cases, 32 AM. J. OF INT. L. 82, 89 (1938).

53. See A. W. B. Simpson, Cannibalism and the Common law (1984).

54. 14 L. Rep. 273 (Q.B.D. 1884). 
will justify him in deliberately taking another's life to save his own. In this case the weakest, the youngest, the most unresisting, was chosen. Was it more necessary to kill him than one of the grown men? The answer must be "No"-

"So spake the Fiend, and with necessity, The tyrant's plea, excused his devilish deeds."

It is not suggested that in this particular case the deeds were "devilish," but it is quite plain that such a principle once admitted might be made the legal cloak for unbridled passion and atrocious crime. ${ }^{55}$

The English court in Queen v. Dudley is in accord with Islamic law; the American court in U.S. v. Holmes ${ }^{56}$ is not. The Holmes court would have permitted the throwing of a passenger overboard to save the rest of the people on a boat if it had been done fairly. However, it found in that case that it was not done fairly. It charged the jury:

But the case does not become "a case of necessity," unless all ordinary means of self-preservation have been exhausted. The peril must be instant, overwhelming, leaving no alternative but to lose our own life, or to take the life of another person. An illustration of this principle occurs in the ordinary case of self-defense against lawless violence, aiming at the destruction of life, or designing to inflict grievous injury to the person; and within this range may fall the taking of life under other circumstances where the act is indispensably requisite to self-existence. For example, suppose that two persons who owe no duty to one another that is not mutual, should, by accident, not attributable to either, be placed in a situation where both cannot survive. Neither is bound to save the other's life by sacrificing his own, nor would either commit a crime in saving his own life in a struggle for the only means of safety.

But, in addition, if the source of the danger [sic] have been obvious, and destruction ascertained to be certainly about to arrive, though at a future time, there should be consultation, and some mode of selection fixed, by which those in equal relations may have equal chance for their life. By what mode,

55. Id. at 287-88.

56. United States v. Holmes, 26 F. Cas. 360 (C.C.E.D. Pa. 1842) (No. 15,383). 
then, should selection be made? The question is not without difficulty; nor do we know of any rule prescribed, either by statute or by common law, or even by speculative writers on the law of nature. In fact, no rule of general application can be prescribed for contingencies which are wholly unforeseen. There is, however, one condition of extremity for which all writers have prescribed the same rule. When the ship is in no danger of sinking, but all sustenance is exhausted, and a sacrifice of one person is necessary to appease the hunger of others, the selection is by lot. This mode is resorted to as the fairest mode, and, in some sort, as an appeal to God, for selection of the victim. ${ }^{57}$

There is much similarity between the Islamic and common law systems in the discussion of the substantive aspects of these issues. Homicide is excused in the case of inevitable necessity where selfpreservation is a universal concern. Where homicide is a particular concern, it is debatable, with the English law paralleling the Islamic law theory that necessity is not a defense. ${ }^{58}$

The common law and Islamic law justifications for the doctrine of necessity differ. Common law refers to a doctrine of necessity without more; Ghazāli takes particular pains to limit and define his doctrine of necessity within the context of a textual source. His approach is to find this doctrine based on the intent of the Law as gathered from the sources as a whole. His approach is not entirely foreign to a similar mode of reasoning in the common law system, even though this mode of reasoning is not used to justify the common law doctrine of necessity. There is precedent in the common law for the constitutional limitation of specific statutes based on the intent of the law as gathered from the Constitution as a whole. In In re Quarles and Butler ${ }^{59}$ the United States Supreme Court recognized the right of a citizen to inform federal officers that the defendant was violating the internal revenue laws:

The right of a citizen informing of a violation of law, like the right of a prisoner in custody upon a charge of such violation, to be protected against lawless violence, does not depend upon any of the Amendments to the Constitution, but arises out of the creation and establishment by the Constitution

57. Id. at 366-367.

58. For further discussion on this issue, see J. Makdisi, Justification in the Killing of an Innocent Person, 38 Clev. Sr. L. Rev. 85 (1990).

59. 158 U.S. 532, 15 S.Ct. 959, 39 L. Ed. 1080 (1895). 
itself of a national government, paramount and supreme within its sphere of action. Both are, within the concise definition of the Chief Justice in an earlier case, "privileges and immunities arising out of the nature and essential character of the national government, and granted or secured by the Constitution of the United States." 60

Such an approach is essentially the method of reasoning by maslaha in Islamic law. It is not prevalent in common law development because it is considered legitimate to expand notions of common law justice through judicial decree which is ultimately sanctioned as precedent by the mere fact of stare decisis (to stand by the decision). In Islamic law, the concept of judge-made law is rejected in favor of God-made and jurist-elaborated law. Adherence to the textual sources is thus a necessary part of legal argument in order to legitimize development in the law. In particular, when there is no textual provision to justify a certain legal principle, the concept of maslaha permits a more expansive reading of the textual sources as a whole - but legitimacy still derives from these sources.

Thus we find Ghazāli, the arch-conservative, advocating even the limitation of a general Koranic provision through the concept of maslaha. In the same way as Quarles found a right to report violations of the law based on the Constitution as a whole, Ghazāli asserts the ability to expand one's vision of the flexible reaches of the Law to include the principle of national self-preservation, despite the killing of innocent Muslims used as shields, based on the sources as a whole where there is no one single provision to govern. However, he is careful to limit it to include only cases of necessity, definitiveness and universality.

In general, Ghazāli advocates restraint in the development of Islamic law. Maslaha does not operate as a principle of public policy to alter the principles of law in the sources. Ghazali provides an example in the case of the ruler who broke the rules of the month of Ramadan fast. The prescribed penalty of manumitting a slave could not be rejected in favor of a penalty requiring a fast of two consecutive months, even if the prescribed penalty was not a deterrent from breaking the rules and the two-month fast was. Ghazāli finds:

This position is invalid and contrary to the text of the Book by [this invalid method of reasoning by] maslaha; and the opening of this door leads to changing all the restraints in

60. Id. at 536 (citations omitted). 
the laws and their textual sources by reason of a change in circumstances. If that were then discovered in the doings of the scholars, the confidence of sovereigns in their legal opinions would not be obtained and they would think that everything they gave a legal opinion on would be a corruption by personal opinion $\left(\mathrm{ra}^{\prime} \mathrm{y}\right) .^{61}$

Ghazāli is adamant that maslaha is the preservation of the understood intent of the Koran, sunna and consensus. The use of this concept for anything else is legislating ${ }^{62}$ - a function that belongs to God alone. Therefore, there should be no dispute over the concept except in the case of two opposing maslahas or two opposing intents, in which case the stronger is to be preferred..$^{63}$ For example, the existence of coercion permits the declaration of apostasy, the drinking of wine, the consumption of another's good, the breaking of the fast and the abandonment of prayer, because the prohibition of bloodshed carries more weight than these other prohibitions. ${ }^{64}$ The consumption of another's goods in the state of coercion is known to be preferred by many indications in the Law. ${ }^{65}$

Ibn Taymiya ${ }^{66}$ has another concept of maslaha. Rather than confining maslaha to the case of necessity defined by Ghazāli's five principles, he permits the use of maslaha generally to obtain a benefit or avoid a harm, as long as it does not contradict anything in the sources. According to Ibn Taymiya, the sources indicate in some way a complete guide for the proper behavior of mankind because God has provided a complete religion for His people through the Prophet Muhammad. ${ }^{67}$ However, there are times when a benefit is not the subject of a direct text or qiyas. In such a case the benefit may be perceived through the use of reason, because reason can distinguish between truth and falsehood, what is beneficial and what is vitiating. This method of developing rules of law, neither prescribed by nor in contradiction to the sources, is called maslaha mursala. ${ }^{68}$ In the absence of such a maslaha, the situation is permitted (ibāha). ${ }^{69}$

61. Mustasfā, supra note 40, at 285-86 (Author's translation from Arabic); see KERR, supra note 5 , at 92.

62. MustasfäA, supra note 40 , at $310-11,315$.

63. KERR, supra note 5 , at 96 .

64. Mustasfä, supra note 40 , at $311-12$.

65. Id. at 314 .

66. Died 1328.

67. 5 Ibn Taymiya, Majmü'at ar-Rasā'il. wa Masä'il 23 (n.d.); see Kerr, supra note 5 , at 87 .

68. 5 Ibn Taymiya, Majmū'at ar-Rasā'il wa Masā'il 22 (n.d.).

69. Regulation (siyāsa shar îya) in Islam. KERR, supra note 5 , at 88. 
It is interesting to note the development in the concept since Ghazāli. Ibn Taymiya appears to define mursala as not textually specified, while Ghazāli defines it as not specified by one particular text but rather by many combined. Benefit is dictated by the sources for Ghazali ; it is dictated by reason within bounds set by the sources for Ibn Taymiya. The latter is an important step toward making the law more flexible. Giving reason free play within certain bounds to deal with new situations, without trying to fit them within a preconceived system, makes it easier to implement the needs of a changing society. The mufit, the giver of legal opinions, must use his knowledge of society and life in general to apply the broad values of the legal sources to the specific instances of particular cases. The Koran and sunna prescribe rights and values in general abstract terms; the mufti helps specify how these general rights and values are to be weighed in particular circumstances given other principles, social goals or political aims.

On the other hand, the degree of flexibility actually permitted in the development of law is a function of interpretation. Although Ibn Taymiya opens the way for a more flexible concept of legal reasoning, he is careful to observe his own cardinal principle that nothing in the law should contradict a textual source. ${ }^{70}$ With a well-developed concept of qiyās (reasoning by analogy based on textual sources) this limitation still means a severe restriction on the use of reason as a basis in itself for legal development. A jurist is not permitted to stride off on his own to fill in gaps in the law, using his own arbitrary personal discretion, or even discretion based on some theory of utilitarianism or natural justice inherent in his conscience. This would be contradictory to the very nature of Islamic law as a system of revelation. Rather the mufti is bound to determine a legal rule by reference to general principles of human welfare in the Koran and sunna.

There is one jurist, however, who represents a very liberal view. Tawfi ${ }^{1}$ claims that every human interest is a necessity and the supreme determining factor in constructing a rule of law. He bases his claim on the tradition of the Prophet which says, "Do not inflict injury nor repay one injury with another." 72 If a human interest conflicted with a provision in the Koran or sunna, then, he says, the latter would be

69. Regulation (siyāsa shar'iya) in Islam. KERR, supra note 5, at 88 .

70. IsTIHSĀN, supra note 19, at 455 (6-8); see KERR, supra note 5, at 79.

71. Died 1316. Tawfi's views as described here are elaborated in KERR, supra note 5 , at $97-102$.

72. Id. at 97 . 
restricted or clarified. This position adopts a natural or social justice approach to Islamic law which finds its ultimate reference point not in the Koran or sunna, but rather in human reason. It leaves the door wide open for the use of human discretion in the determination of legal rules. Not surprisingly, Tawfi's position is considered an extreme exception to the traditional view. ${ }^{73}$ However, it has become in modern times a major source of support for a new concept of maslaha.

\section{The Role of Human Judgment in the Decision of Hard CASES}

Qiyās, istihsān and ististāh are three methods by which Islamic law is elaborated. Each method has the potential for abuse as the vehicle for arbitrary personal opinion, but such abuse is rejected in legal theory. In practice each of the three methods encourages the use of human judgment respectively to assimilate, distinguish and plug the gaps between legal cases.

Discretion is needed to work these methods, much the same as it is needed in the common law, but discretion is not to be confused with arbitrary opinion. In the case of Norway Plains Co. v. Boston $\mathcal{E}$ Maine $R . R .{ }^{74}$ two parcels of merchandise were destroyed by an accidental fire after they were deposited on the railroad platform at the point of destination by the railroad transporting the parcels. The question raised in the case was whether the railroad continued its status as a common carrier of the goods after the deposit or became merely a warehouseman. The settled rule of law was that railroads in transit were strictly liable for accidental fires regardless of fault because of their status as common carriers. As a warehouseman the railroad would have been liable only for failure to exercise care in the custody of the goods. Because the railroad had not breached any duty of due care it would have been liable in the status of a common carrier but not in the status of a warehouseman. In this case the court decided that the railroad was no longer a carrier but rather a warehouseman after its deposit of the goods on the platform. The court determined that the common basis (asl in Islamic law) behind the common carrier rule was the state of being in transit.

Such judgment was ultimately a matter of opinion, but it was not arbitrary so long as the court sought the reason behind the different duties of common carriers and warehousemen. It would have been

73. Id. at 100-01.

74. 1 Gray 263 (Mass. 1854). 
arbitrary if the court had decided the case based on personal preference or whim. In the same way, two Islamic jurists may disagree over whether the sale of unripe fruit is a risky sale and both may use reasoning by qiyās legitimately to arrive at different conclusions. Their experiences may be different and each may define the term "risk" differently, although it may be the best way their experiences permit. If either or both of the jurists are inclined to define "risk" in such a way as to satisfy a personal preference or whim, then their decision would be arbitrary personal opinion.

Turning from qiyās to istihsān, we find the same leeway for the use of discretion. Take, for example, the Berenson case mentioned earlier. ${ }^{75}$ By narrowing the broadly stated principle in the Spritz line of cases so that it did not conflict with the principle in the Salter line, the court reconciled the cases without disturbing the concept of precedent. Yet, the manner by which the legal principles in these cases were narrowed or broadened demonstrates the role of human discretion in giving weight to factual similarities and differences that did not necessarily have the same weight in the original cases. The judge has a certain leeway for using his discretion in distinguishing between and choosing from the principles of prior cases those which he will apply to the case at hand; and the limits to which he may go are not clearly defined. As Hart and Sacks point out:

Assuming that either some of the plaintiff's cases or some of the defendant's cases had to be qualified or overruled, which party's? Is it an overstatement to say that, considering the function in primary private activity of the arrangements in question, considering known community attitudes, and considering established policies of the law in relation to comparable problems, this question could be answered with great assurance? ${ }^{76}$

The discretion which the judge uses in deducing a legal decision from precedent requires a distinct separation to be made between the absolute syllogism and the legal syllogism. The former may be exemplified in the statements: All men are mortal; Socrates is a man; therefore, Socrates is mortal. Legal logic does not work in this manner since there are a number of competing variables that must be taken

75. This section from here through text at footnote 77 is reprinted (with minor modifications) from J. Makdisi, Legal Logic and Equity in Islamic Law, 33 Ам. J. оF Coмp. L. 63, 87-89 (1985).

76. HART \& SACKs, supra note 28 , at 420 . 
into account. The priority of these variables in the decision-making process may be determined ultimately by the judge's own inclinations in the matter. The process appears to be a combination of two approaches:

As a matter of fact, men do not begin thinking with premises. They begin with some complicated and confused case, apparently admitting of alternative modes of treatment and solution. Premises only gradually emerge from analysis of the total situation. The problem is not to draw a conclusion from given premises; that can best be done by a piece of inanimate machinery by fingering a keyboard. The problem is to find statements, of general principle and of particular fact, which are worthy to serve as premises. As matter of actual fact, we generally begin with some vague anticipation of a conclusion (or at least of alternative conclusions), and then we look around for principles and data which will substantiate it or which will enable us to choose intelligently between rival conclusions. No lawyer ever thought out the case of a client in terms of the syllogism. He begins with a conclusion which he intends to reach, favorable to his client of course, and then analyzes the facts of the situation to find material out of which to construct a favorable statement of facts, to form a minor premise. At the same time he goes over recorded cases to find rules of law employed in cases which can be presented as similar, rules which will substantiate a certain way of looking at and interpreting the facts. And as his acquaintance with rules of law judged applicable widens, he probably alters perspective and emphasis in selection of the facts which are to form his evidential data. And as he learns more of the facts of the case he may modify his selection of rules of law upon which he bases his case.

I do not for a moment set up this procedure as a model of scientific method; it is too precommitted to the establishment of a particular and partisan conclusion to serve as such a model. But it does illustrate, in spite of this deficiency, the particular point which is being made here: namely, that thinking actually sets out from a more or less confused situation, which is vague and ambiguous with respect to the conclusion it indicates, and that the formation of both major premise and minor proceed tentatively and correlatively in the course of analysis of this situation and of prior rules. As soon as acceptable premises are given and of course the judge and jury have eventually to do with their becoming accepted - 
and the conclusion is also given. In strict logic, the conclusion does not follow from premises; conclusions and premises are two ways of stating the same thing. Thinking may be defined either as a development of premises or development of a conclusion; as far as it is one operation it is the other. ${ }^{77}$

Ististah provides the most open-ended means for the development of Islamic law. The concept is generally one of strict adherence to the revealed sources of law, without intervention by human reason to form values or rights; value judgments are provided by the Koran and sunna. But human reason is used to derive from these scriptural values specific rules to govern human behavior, and it is in this process that human discretion plays a role. Maslaha is used primarily to fill the gaps in the matrix of specific rules. Furthermore, this process also leaves room for change once specific rules are decided. There might be a change in social circumstances. Although the primary texts are considered divine and immutable, interpretation of these texts must change in light of changed customs, needs, interests, conditions, times and environments. ${ }^{78}$ Human discretion not only ascribes weights to particular events and circumstances but may change these weights when circumstances change.

The problem in all of this is the fact that no amount of restraint can effectively prevent the use of arbitrary opinion if a judge or jurist so chooses. Because legitimate differences of opinion may exist in a particular case, it is difficult for an observer to determine whether a jurist has decided a case legitimately or arbitrarily. Some scholars, such as Roberto Unger, see law as a form of politics, in which objective legal rationality is an illusion and the most that should be hoped for is the "potential rationality of the normal modes of moral and political controversy." 79 Others, such as Ronald Dworkin, feel that there is a sense of community morality according to which the judge feels com-

77. Dewey, Logical Method and Law, 10 Cornell L.Q. 17, at 23 (1924). Dewey later compares this process to an ocean in a storm with a series of waves: "suggestions reaching out and being broken in a clash, or being carried onwards by a cooperative wave." John Dewey, Art As Experience 38 (1934).

78. See KERR, supra note 5, at 84, abstracting from Khallaf's summary of the position of the proponents of ististah as follows: "Times change and new problems arise; what was once maslaha becomes an evil. Unless the mujtahids are allowed to use istislah, the Shari'a will fail to provide for the people's interests, which would clearly be contrary to its intent."

79. Unger, The Critical Legal Studies Movement, 96 Harv. L. Rev. 563, at 579 (1983). 
pelled to decide cases. ${ }^{80}$ This debate applies to Islamic and common law alike.

\section{Observations on the future of Islamic Law}

After the thirteenth century, creativity in Islamic legal development was stifled. ${ }^{81}$ Rigid adherence to given rules of law became more the norm than the exception. The reasons given are varied. The important point is that after several centuries of stagnation there is now a concerted effort in many parts of the Islamic world to return to a dynamic system of Islamic law. One of the means used to loosen the rigid formalism of the law that developed in these last years has been a rejuvenation of the concept of maslaha; only, maslaha now takes on a new meaning.

One of the leading advocates for social reform in the Muslim world around the turn of this century was Rashid Ridā. ${ }^{82}$ His philosophy is based on a utilitarian methodology which defines justice in Islamic law as natural justice reflected in the revealed law as well as determined through independent contemplation. ${ }^{83}$ The emphasis thereby shifts from a legal system conceived as totally dependent on revelation to one that uses a combination of reason and revelation as a legal foundation. Ridā holds that there is no conflict between the rights and obligations of Islamic law as dictated by the scriptural sources and those dictated by natural human moral disposition. The primary purpose of both is to secure man's welfare, and man can do that for himself as well as be instructed by the Koran and sunna. Hence, Islam does not create justice, it teaches men how to conform to it. ${ }^{84}$ Ridā attempts to break the pattern of strict reliance on the primary sources, and he pushes the concept of maslaha to the limit. He finds support for this theory in part based on Tawfi's work, a liberal thirteenth century view. ${ }^{85}$

The broadly-applied maslaha advocated by Ridā was not embraced wholeheartedly by Islamic jurists. ${ }^{86}$ One of the reasons may be in the

80. Ronald Dworkin, Taking Rights Seriously Chp. 4: Hard Cases 81-130 (1978); see H.L.A. Hart, The Concept of Law 121-150 (1961).

81. George Makdisi, The Rise of Colleges: Institutions of Learning in ISLAM AND THE WEST at 289-91 (1981).

82. Muhammad Rashīd Ridā (1865-1935) was Muhammad 'Abduh's leading biographer and the founder and editor of the journal Al-Manär.

83. See KerR, supra note 5, at 157.

84. Id. at $156-57$.

85. Id. at 207; see text at supra note 73 .

86. Id. at 195-197, 219-223. 
failure of Islam to separate the judicial from the executive branch of government. Contrary to the common law system where judges who are responsible for the development of doctrine through case law are independent of the governing power, the Islamic jurists who developed doctrine had no formal authority of office except at the pleasure of the sovereign. Therefore, it was necessary to find sufficient constraints on changing the law itself to restrain the otherwise unbridled power of government. This reason for the limited success of maslaha among the jurisconsults is suggested by the following passage from Rashĩd Ridā 's book Yusr al-Islam:

Most of the 'ulamā' of the Community avoided explicit reference to the principle [of maslaha] because of their fear as Qarāfi says - that tyrannical leaders would take it as an excuse for following their own desires and imposing their absolute power on the property and persons of the population. The 'ulamā' therefore thought to guard against this by tracing all laws back to revealed sources, even when this necessitated recourse to [so-called] hidden analogies. They converted the notion of masalih mursala into one of the most technical forms of the 'illa in qiyass, so that it was not subject to the interpretation of princes and governors. This fear was justified at the time, but the Community did not thereby guard itself sufficiently against the desires of its rulers, for every tyrant could always find corrupt 'ulamā' to prepare the way for him to follow his own inclinations to some extent. ${ }^{87}$

Whether or not the Muslim accepts a natural law theory of justice, there will most likely continue to be significant dependence put on the Koran and sunna as sources for a framework of human values and rights. The meaning of Islam is submission to God through the law, the path provided by the Revelation in the Koran and sunna. The Islamic tradition has flourished and floundered but has never really given up this idea which gives legitimacy to Muslim values. The problem, then, is to focus on the manner in which principles are interpreted in the Koran and sunna today, if these sources still provide a basis for legitimacy in the law. A hard look must be taken not at the general provisions of these sources but at the concrete applications of principles from these general provisions, the area in which human discretion has and continues to play a significant role.

87. Rashid Ridā, Yusr al-Islām wa Usūl at-TASHrī' AL-'AMm 75-76 (Cairo 1928), translated in KERR, supra note 5, at 195 (footnote omitted). 
There is much room for discussion, debate and disagreement in this sphere. Disagreement is not something new to Islam. In fact khilaf (difference of opinion) was and continues to be an important part of the vitality of Islamic law. What cannot be done is to impose principles from without. One who is a stranger to a given culture and legal system cannot dictate what is right and wrong in the concrete applications of human rights and values in another culture. While the cutting of a hand for theft may appear to be barbaric and inhumane to one culture at one point in time, is it any more barbaric than the execution of criminals in an electric chair? Perhaps both are violations of human rights and values, but to determine this, the discussion must move from the abstract to the concrete instance. In the decision of the concrete instance, it has to probe for the efficient cause and even further for the hikma, the wisdom of the legal rule ${ }^{88}$ Sometimes this probe arises not by direct indications in the sources but by the jurist's own judgment as maslaha mursala. ${ }^{89}$ In any case the attempt should be made for a reasoned elaboration of the law. It is at this point that the discussion will lead to true understanding and that social and political philosophies will be laid bare.

In other words, it is not enough to talk about general principles of human rights and values. The flexible reaches of the law which lie in the consideration of illa and hikma must be examined to determine the real blocks to a practical implementation of perceived human rights and values. Ultimately, it will be seen that it is not the law that is doing the blocking. It is either misunderstanding or an opposed social or political philosophy. The law can be manipulated within the bounds permitted by its flexibility to express the currently felt needs of society.

Even the most conservative view of maslaha held by Ghazāli permitted a direct contradiction of the Koranic prohibition on killing by permitting the killing of Muslim prisoners used as shields in wartime. Other views were more liberal, and modern times offer the most liberal views. However, Islamic law has been stagnant to the extent that it has not followed the classical system of legal reasoning, it has abandoned it, or has been forced to abandon it in favor of Western modes of thought. As parts of Islam attempt to reinstitute these traditions, they find that the law has lost touch with the reality of present-day concerns.

88. The underlying reason for an efficient cause of a rule is called hikma. The hikma explains the rational comprehensibility of the rule. For example, the 'illa in the prohibition of wine is intoxication; the hikma is that intoxication is bad. KeRR, supra note 5 , at 67,73 .

89. KERR, supra note 5 , at 81 . 
What would it be like if we tried to adapt our Constitution to modern social needs two hundred years after the doors of creative legal development were closed? The attempt to identify presently felt needs and problems with the legal solutions of an outdated legal system may prove too high a price to pay for tradition. The Muslim people are presently wrestling with this problem as they throw off the yoke of foreign domination, an imposition which has done much to destroy their cultural identity. It may be that a new legal system is needed, one which retains the primary sources but which no longer conforms to the classical model in methodology. New techniques and methods of legal reasoning may be instituted to accommodate social change.

The deliberate misinterpretation and suppression of Islamic legal principles in the same vein as our fictional judge who found the Indian guilty of violating the Small Birds Act should never be permitted. This obfuscation leads to confusion and misunderstanding not only among foreign cultures but within the Islamic culture itself. It will ultimately lead to unrestrained arbitrariness and inevitable unjustness. What is needed is an educated self-disciplined approach to the law by those who are well-versed in the law and in tune with society.

The lawyers, jurists, and judges of society are the builders of its legal system. They are empowered with a sacred trust because within the flexible reaches of the law they have a chance to incorporate, modify or remove that which is not in accord with the theory of the legal system and society, a theory promoting human welfare in accord with societal change and evolution. Without a total denial of the Islamic legal system, it is still possible to trace this path without too much rigidity nor too much flexibility. The system itself prescribes such a path in the very concept of Shari'a. But it will be the Muslim who understands both the law and culture who will decide this question. 
